\title{
FACTORS INFLUENCING E-COMMERCE ADOPTION: EVALUATION USING STRUCTURAL EQUATION MODELLING (SEM)
}

\author{
Kit-Yeng Sin* \\ Universiti Malaysia Sarawak \\ Mun-Chong Sin \\ Universiti Teknologi Malaysia
}

\begin{abstract}
Electronic commerce (e-commerce) has become a rapidly growing phenomenon to date. A peep into the exponential growth of the main players in this industry reveals a large reservoir of market potential for ecommerce. Nevertheless, the prevalence of e-commerce adoption has attracted attention from the government, retailers, and academicians to place specific focus on this area. As such, this study determined the correlation between Chief Executive Officer's (CEO's) technology knowledge, relative advantages, and competitive pressure through the lens of Tornatzky and Fleischer's (1990) Organisational, Technological, and Environmental (OTE) model in order to probe into the adoption of e-commerce. CEOs and managers of Small and Medium Enterprises (SMEs) established in the Northern states of Malaysia were selected as the subject of analysis. A total of 283 out of 364 questionnaires distributed were valid for analysing and testing the hypotheses. Next, the gathered data were analysed using Statistical Package for the Social Sciences (SPSS) version 18.0 and Analysis of a Moment Structures (AMOS) version 16.0. The Structural Equation Modelling (SEM) was employed to assess model fit and to test hypotheses. As a conclusion, CEO's technology knowledge and relative advantage displayed significantly positive influence upon adoption of ecommerce, whereas competitive pressure exhibited insignificant impact upon adoption of e-commerce. In precise, the insignificant influence of competitive pressure on e-commerce implementation appeared to be driven by other unseen variables worthy to be discovered. For future research, a comparison study can be conducted by selecting samples both from employers and employees, as well as other multiple variables associated with e-commerce adoption, so as to keep sampling bias at a minimum level.
\end{abstract}

Keywords: E-commerce, CEO's technology knowledge, relative advantage, competitive pressure, Small and Medium Enterprises (SMEs), Structural Equation Modelling (SEM).

Received: 1 June 2019

Accepted: 14 September 2020

\section{INTRODUCTION}

In this digital age, e-commerce appears to be trending to enhance businesses amongst entrepreneurs at anytime and anywhere. Nevertheless, e-commerce is somewhat known in the provision of its concept, instead of its usage and practice amidst many. Several conglomerates

\footnotetext{
* Corresponding author: Kit-Yeng Sin, Faculty of Economics and Business, Universiti Malaysia Sarawak, 94300 Kota Samarahan, Malaysia. Email: kysin@unimas.my
} 
across our nation have successfully ventured into the adoption of e-commerce, while some budding and small business organisations are hesitant in implementing e-commerce, despite reckoning its significance in the present and future business undertakings.

At the moment, several free open source software programs are available, whereby anyone across this globe can choose any software program for implementation. Hence, the cost of implementing Internet-based technology is bound to decline due to emergence of such free software programs. Additionally, the government has begun providing grants and incentives to assist enterprises in minimising their high start-up costs, their burden of employing new technology, and their pain associated with possibility of failure in adopting e-commerce. This was supported by the Malaysian Digital Economy Corporation (MDEC)'s chief executive officer, Surina Shukri, that government allocation within National Economic Recovery Plan (PENJANA) can assist approximately 907,065 SMEs to reach global buyers and international e-market places by year 2020 (MDEC, 2020).

Despite the plentiful stimulators and motivators that encourage enterprises to adopt technology for business purposes, participation amongst enterprises in e-commerce adoption seems to be rather low. Based on SME annual report 2019-2020, it is revealed that the adoption of ecommerce among SMEs is still in the infancy stage. According to the report, more than $90 \%$ of SMEs in Malaysia have a weak environment for technology application and lack in connectivity in which 10\% out of 900,000 SMEs in Malaysia owned websites, while the residual $90 \%$ did not have any online portal and carried out their business operation in the conventional manner (SME Corp, 2020). It is assumed that conducting business online might stumble upon their mind, but the initial step to implement the adoption is discouraged. This figure is unexpectedly low considering the various incentives and grants provided by the government to promote the uptake of E-Commerce by SMEs. It is believed that by 2021, at least $50 \%$ of global Gross Domestic Product (GDP) will originate from digitalization, with growth in every industry driven by digitally-enhanced offerings, operations and relationships, including SMEs. In this regard, organizations that are slow to digitize their offerings and operations over the next three years will find themselves competing for only a minority - of their market segments' opportunities.

According to the Valuation and Property Services Department's (JPPH) Property Market Report 2017, one of the initiative that is expected to support the e-commerce performance is the establishment of a Special Border Economic Zone in Bukit Kayu Hitam, which will be the new attraction for both domestic and foreign investors in the northern zone of Malaysia (Mahalingam, 2018). Therefore, this pressing issue motivated the authors to further explore the trend of ecommerce adoption among SMEs in the Northern region of Malaysia. The findings of this study should reveal the relevant factors to inculcate SMEs conduct their businesses using appropriate technology.

\section{LITERATURE REVIEW}

\subsection{E-commerce Adoption}

Through the case studies of Air-Asia, Lazada, Rakuten Malaysia, Maybank, Ipay88, and Digital New Asia (DNA), adoption of e-commerce in Malaysia is bound to expand to offer space to 
conglomerates for global market penetration and local players to establish partnerships for foreign trade, hence escalating the growing number of market research firms. In fact, Goldman Sachs predicted that the Malaysian e-commerce trade to be worth of a whopping US\$ 1.1 billion in year 2012, along with 30\% year-on-year growth, whereas the Euromonitor proposed ecommerce trade worth US\$ 623 million by year 2016. Additionally, the Central Bank of Malaysia disclosed that the overall transaction value in year 2013 from international debit cards and credit cards reached US\$ 30 billion, whereby US\$ 3.6 billion (12\%) reflected e-commerce or Internet transactions.

Vast evidences are available to display the benefits of adopting e-commerce. Eid (2011) assessed e-commerce adoption in business management and discovered that e-commerce did have a positive impact on customer satisfaction, not only within the organisation, but also extended to market share. Stroehle (2008) found that e-commerce application in the trade had an impact on enhancing the efficacy of marketing activities, whereas Allan and Fjermestad (2001) indicated that e-commerce applications had a positive impact on the expansion of new product, apart from improving product quality, which in turn, intensified both market share and customer satisfaction.

\subsection{Tornatzky and Fleischer's (1990) OTE model}

Various studies have assessed e-commerce and its related determinants within varying contexts, including developed and developing nations. Most the these researches examined the correlation between OTE and adoption of e-commerce by SMEs (see Seyal \& Rahman, 2003; Wu, Mahajan, \& Balasubramaniam, 2003; Lertwongsatien \& Wongpinunwatana, 2003; Chang, 2006; Almoawi, 2011; Elmazi, Vukaj, Gega, \& Elmazi, 2011). Tornatzky and Fleischer's (1990) OTE model, which is composed of organisational, technological, and environmental attributes, has been extensively applied by many organisations to identify factors that influence innovation adoption (Kiarie, Henry, \& Rong, 2018; Awa, Ojiabo, \& Orokor, 2017; Awa, Ukoha, \& Emecheta, 2016; Awa, Ukoha, \& Emecheta, 2015), wherein e-commerce is the innovation adoption that is discussed in this study.

Tornatzky and Fleischer's (1990) OTE framework highlights organisational, environmental, and technological attributes, which have been proven to influence an organisation to embrace technology. The context of organisational includes formalisation, scope and firm size, centralisation, human resource and its sufficiency, and administrative intricacies. Next, the environmental context describes the nature of business carried out, including its contenders, the main players, and the government, to name a few. As for the technology attribute, it is composed of external and internal technologies, such as technologies available in the market and in the firm.

\subsection{Organisational Context}

Most studies have reported the positive correlations between adoption of e-commerce and organisational attributes (see Wu, Mahajan, \& Balasubramanian, 2003; Lertwongsatien \& Wongpinunwatana, 2003; Lip-Sam \& Hock-Eam, 2011; Elmazi et al., 2011; Shah Alam, Ali, \& Mohd Jani, 2011, Awa et al., 2017), while some discovered contradicting outcomes (see Chang, 2006; Almoawi, 2011). Chang (2006) and Almoawi (2011) found that owner's innovativeness and owner's technology knowledge had insignificant relationship towards e-commerce adoption. This outcome had motivated the authors of this current study to prove into the aspect of CEO's 
technology knowledge towards e-commerce implementation across organisations. Hence, CEO's technology knowledge was selected as a variable in this study, mainly because the authors opined that the power of advanced technology knowledge acquired by leader has a dominant effect on the implementation of e-commerce in this age of rat race knowledge-based competition.

\subsection{Technological Context}

Variables related to technological context are vast, such as issues related to network security (Doherty \& Fulford, 2006), preliminary start-up costs, cost of system amalgamation, as well as expenditure of buying and installing e-commerce hardware items and software programs. Despite security issues and affordability, other factors that have affected organisational e-commerce adoption are quality of IT infrastructures, for instance, consistency of network and bandwidth. A number of researchers have exemplified the effects of technological context on e-commerce and mostly have reported its positive correlation with e-commerce implementation (see Lertwongsatien \& Wongpininwatana, 2003; Grandon \& Pearson, 2004; Mac Gregor \& Vrazalic, 2008; Gilaninia, Danesh, Amiri, Mousavian, \& Eskandarpour, 2011; Elmazi et al., 2011; Shah Alam et al., 2011; Wanyoike, Mukulu, \& Waititu, 2012; Saffu, Walker, \& Mazurek, 2012, Awa et al., 2016). Nonetheless, a handful of studies revealed opposite outcome. In Singapore, Soh, Mah, Gan, Chew and Reid (1997) scrutinised the practice and the perceptive of new-fangled Internet adopters, in which a negative correlation was discovered between relative advantage and adoption of e-commerce. Similarly, Seyal and Rahman (2003) found insignificant correlation between implementation of e-commerce and relative advantage. Such findings portray conflict in findings and had prompted the authors of this study to investigate the association between relative advantages and adoption of e-commerce amidst SMEs established in Malaysia's Northern states.

\subsection{Environmental Context}

Many researches pertaining to environmental attributes have displayed the positive correlation with adoption of e-commerce (see Lertwongsatien \& Wongpinunwatana, 2003; Grandon \& Pearson, 2004; Lip-Sam \& Hock-Ean, 2011; Elmazi et al., 2011; Saffu et al., 2012, Awa et al., 2017). Lertwongsatien and Wongpinunwatana (2003) carried out a study in Thailand and discovered that those exposed to technology were more likely to embrace innovative system and adopt e-commerce. Similarly, Almoawi (2011) reported that those who adopted e-commerce had higher tendency to accept innovative system within competitive context. On the contrary, Chang (2006) found that competition intensity was negatively related to adoption of e-commerce. Such divergence in findings led the authors of this study to examine the relationship between adoption of e-commerce and competitive pressure amongst SMEs established in Malaysia's Northern states. Figure 1 illustrates the new theoretical framework built in this study, along with the subsequent development of study hypotheses. 
Figure 1: Theoretical Framework based on Tornatzky and Fleischer's (1990) OTE model

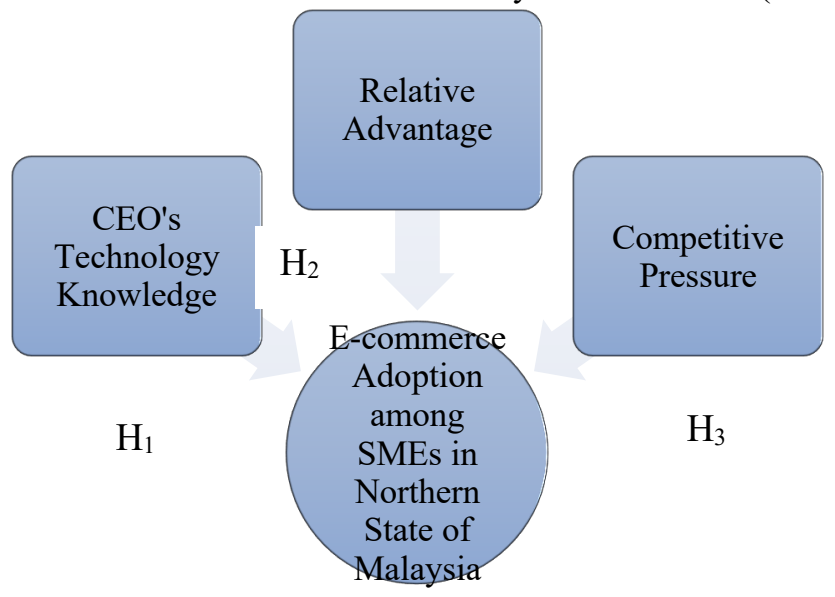

$\mathrm{H}_{1}$ : CEO's technology knowledge under organisational context has a significantly positive influence on e-commerce adoption.

$\mathrm{H}_{2}$ : Relative advantage under technological context has a significantly positive influence on ecommerce adoption.

$\mathrm{H}_{3}$ : Competitive pressure under environmental context has a significantly positive influence on ecommerce adoption.

\section{RESEARCH METHODOLOGY}

The relationships of CEO's technology knowledge, relative advantage, and competitive pressure with adoption of e-commerce had been assessed in this study. In adopting the quantitative approach, questionnaires were distributed to managers and CEOs of SMEs established within the Northern Malaysia states, which includes Perlis, Kedah and Penang. It is believed that managers and CEOs of SMEs possess appropriate understanding and exposure to Internet transaction functionalities and capabilities. Besides, they have the main power to decide whether to adopt Ecommerce in an organization vis a vis. The probability sampling technique, or the simple random sampling to be in precise, was applied in this study due to generalisability and minimum bias reasons. Simple random sampling was used to sample from the SMEs list provided by Small and Medium Industries Development Corporation (SMIDEC) website under the "Penang, Kedah, Perlis" directory and the Penang Development Corporation (PDC) factory list. As recommended by Cavana, Delahaye, and Sekaran (2011), the number of sample subject is targeted at around 364. Accordingly, more than 364 questionnaires were distributed in the actual survey to selected respondents so as to attain the desired sample size, in which 283 questionnaires had been returned upon completion, hence signifying a response rate of $77.75 \%$. The items in the questionnaire had 5-point Likert-type scale. Next, the gathered data were analysed with two analytical instruments, which were AMOS and SPSS. 


\section{RESULTS AND DISCUSSION}

\subsection{Pilot Study}

Before the actual survey was conducted, a pilot test was performed as pre-test amongst 30 respondents in Perlis state after obtaining their permission. A brief explanation was given prior to the 30-minute pilot test at the respondents' workplace and all completed questionnaires were gathered. As a result, all the four tested variables, including CEO's technology knowledge, relative advantage, competitive pressure, and e-commerce adoption, scored exceptional level of 0.80 , as suggested by Sekaran (2003). Since no correction was made to the items, they were retained in their original form.

\subsection{Reliability Analysis}

Table 1: Summary of Reliability Test

\begin{tabular}{cccc}
\hline \hline Variables & No. of Item & Cronbach's Alpha & Remarks \\
\hline CEO's Technology Knowledge & 8 & 0.877 & Good \\
Relative Advantage & 7 & 0.934 & Excellent \\
Competitive Pressure & 4 & 0.893 & Good \\
E-commerce Adoption & 11 & 0.928 & Excellent \\
\hline \hline
\end{tabular}

Table 1 shows that the values of Cronbach's Alpha fell within the range of 0.877 until 0.934. Hence, all items were retained as they satisfied the requirement to exceed 0.70 (Nunnaly, 1978). Additionally, the internal consistency of all four variables had been good at 0.877 . Relative advantage emerged as the variable with the highest reliability. Thus, all selected indicators were retained and used to gather data in the actual survey.

\subsection{Descriptive Analysis}

Table 2: Summary of Descriptive Finding

\begin{tabular}{cccccc}
\hline \hline Variables & N & Minimum & Maximum & Mean & $\begin{array}{c}\text { Standard } \\
\text { Deviation }\end{array}$ \\
\hline CEO's Technology Knowledge & 283 & 1.00 & 5.00 & 2.83 & 1.32 \\
Relative Advantage & 283 & 1.00 & 5.00 & 2.98 & 0.93 \\
Competitive Pressure & 283 & 1.00 & 5.00 & 3.06 & 0.97 \\
E-commerce Adoption & 283 & 1.00 & 5.00 & 2.35 & 1.01 \\
\hline \hline
\end{tabular}

Table 2 depicts mean scores that ranged between 2.00 and 5.00, which showed that all the four variables had moderate scores (Pihie, Bagheri, \& Sani, 2012). Competitive pressure had the lowest score at 2.35, whereas some respondents expressed their disagreement towards the measurement. CEO's technology knowledge and relative advantage with mean scores at 2.83 and 2.98, respectively, signified that the respondents neither disagreed nor agreed with the statements. The outcomes exhibited acceptable variances within the dataset since the standard deviation ranged from 0.93 until 132. This signified that the respondents gave varying views pertaining to the variables tested in this study. 


\subsection{Empirical Testing of the Hypothesised Model}

As several values failed to satisfy the goodness of fit indices (GFI), some items were discarded and the model was regenerated in order to enhance the outcomes, as dictated by the modification indices (MI) (Schumacker \& Lomax, 2004). The following portrays the revised model:

Table 3: Improvement of the Model

\begin{tabular}{ccccccc}
\hline \hline Model & Items & GFI & RMSEA & CFI & $\chi^{2} / \mathbf{D F}$ & TLI \\
\hline 1.Original Model & 30 & 0.730 & 0.076 & 0.845 & 3.778 & 0.805 \\
2. Revised Model & 22 & 0.903 & 0.062 & 0.952 & 3.269 & 0.917 \\
\hline \hline
\end{tabular}

Table 3 displays that the 30 initial items had been decreased to 22 mainly to enhance the overall fit. As a result, all GFI requirements had been satisfied and the GFI value increased to 0.903 from 0.730 (>0.90), as recommended by Hu and Bentler (1999), df/cmin from 3.778 to $3.269(\geq 2 \leq 5)$ (Marsh \& Hocevar, 1985), RMSEA from 0.076 to 0.062 ( $\geq 0.05)$ (Kock, 2011), TLI from 0.805 to $0.917(\geq 0.9)$ (Vandenberg \& Scarpello, 1994), and lastly, CFI from 0.845 to $0.952(>0.95)$ (Kock, 2011).

Figure 2: The Original Hypothesised Model

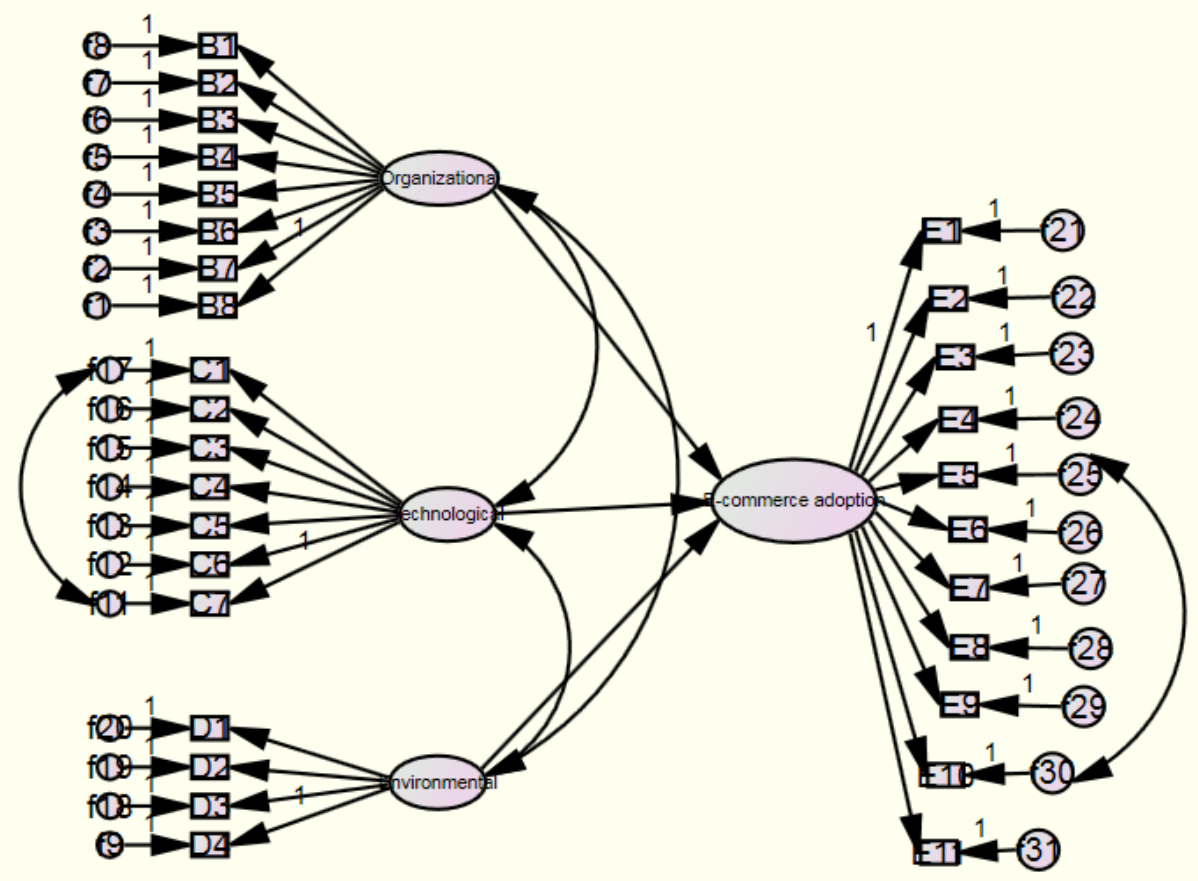


Figure 3: The Revised Hypothesised Model

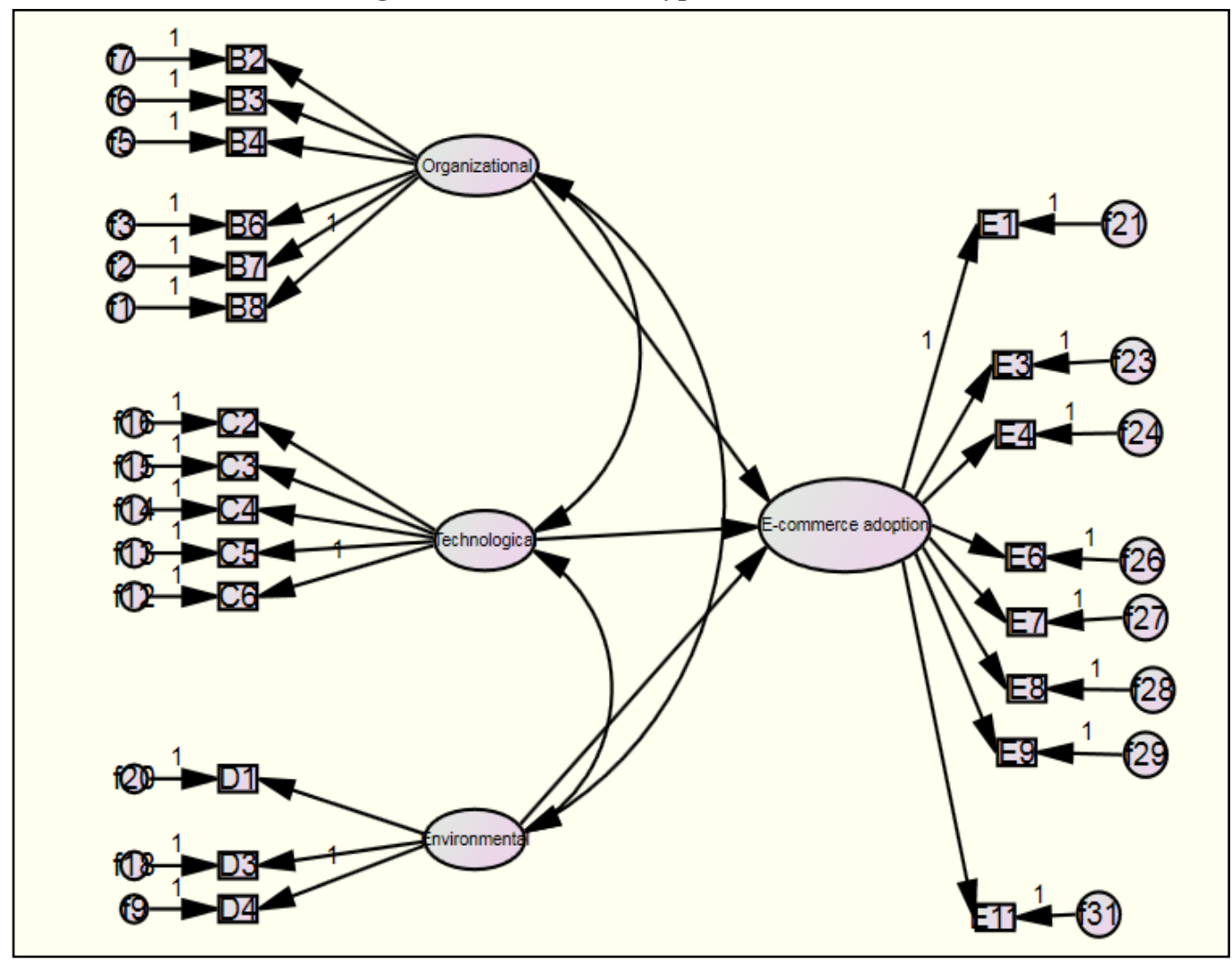

\subsection{Hypotheses Testing Outcomes for Variables with Direct Relationship}

Table 4: Correlations between Exogenous and Endogenous Variables

\begin{tabular}{llcll}
\hline \hline Hypotheses & $\begin{array}{l}\text { Exogenous } \\
\text { Endogenous }\end{array}$ & andStd.Estimate & Critical Ratio & Remarks \\
\hline $\mathrm{H}_{1}$ & $\mathrm{CTK} \rightarrow$ EA & 0.977 & $7.256^{* * *}$ & Supported \\
$\mathrm{H}_{2}$ & $\mathrm{RA} \rightarrow$ EA & 0.843 & $5.396^{* * *}$ & Supported \\
$\mathrm{H}_{3}$ & $\mathrm{CP} \rightarrow$ EA & 0.778 & 1.134 & Not Supported \\
\hline \hline
\end{tabular}

Note: $\mathrm{CTK}=\mathrm{CEO}$ 's technology knowledge; $\mathrm{RA}=$ Relative advantage; $\mathrm{CP}=$ Competitive pressure; $\mathrm{EA}=\mathrm{e}$-commerce adoption

Figure 2 displays the original full hypothesised model while Figure 3 illustrates the hypothesised outcomes retrieved from the revised framework. Based on the revised hypothesized model (Figure 3), the direct effect of CEO's technology knowledge, relative advantage, and competitive pressure on the endogenous variables of e-commerce adoption were presented in Table 4. Ghazali (2005) claimed that path coefficient is deemed significant at 0.05 level when the critical 
ratio exceeds 1.96. Table 4 shows that Hypothesis 1 is supported, wherein CEO's technology knowledge has a significantly positive influence upon e-commerce adoption $(\beta=0.977)(p<0.05)$. Next, Hypothesis 2 is also supported $(\beta=0.843)(p<0.05)$ to display that relative advantage has a significantly positive impact upon adoption of e-commerce. The correlation between adoption of e-commerce and competitive pressure was insignificantly positive $(\beta=0.778)(p<0.05)$ since the critical ratio was below 1.96, hence Hypothesis 3 is not supported.

\section{CONCLUSION}

The study outcomes displayed that two hypotheses are supported out of three. In fact, the correlation of adoption of e-commerce with CEO's technology knowledge had been the strongest $(\beta=0.977, \mathrm{p}<0.05)$. The strong impact of CEO's technology knowledge on adoption of ecommerce seems to be in line with past researches (see Jantan et al., 2001), signifying both CEO's characteristics and personal technology experience as the salient predictors of the actual behaviour in embracing and adopting e-commerce or information system. The second strongest correlation was between relative advantage and e-commerce adoption that had been significantly positive. Such outcome implies that e-commerce implementation by SMEs was influenced by the perception of relative advantages acquired, for instance, network and bandwidth consistency, system amalgamation expenses, expenditure of buying e-commerce hardware and software tools, and preliminary start-up cost. Nonetheless, in tandem with that reported by Chang (2006), Hypothesis 3 is rejected. Despite the insignificantly positive correlation between competitive pressure and implementation of e-commerce, the actual adoption of e-commerce by SMEs appeared to be influenced by other factors. This study displayed more increment in explanatory power of OTE and adoption of e-commerce, in comparison to other studies. The outputs of this study serve as a guideline for future researchers who would like to focus on the benefits and address the related shortcomings. Furthermore, it provides Malaysian SMEs especially those who located in Northern state of Malaysia some informative findings concerning E-commerce that enabling them to exploit better strategies as well as obtain possible advantages and competitive benefits respectively. This study has several limitations, for example, restricted sampling that was limited to CEOs and managers with tertiary academic qualification. Hence, future studies may conduct a comparative study by selecting employees and employers as the study sample, apart from embedding other related variables of e-commerce implementation, such as GST initiative or government support.

\section{REFERENCES}

Allan, E., \& Fjermestad, J. (2001). E-commerce Strategies: The Manufacturer Retailer Customer Relationship. In Proceedings of the $6^{\text {th }}$ Americas Conference on Information Systems (AMCIS 2000) (pp. 872-878). AIS Electronic Library (AISeL).

Almoawi, A. R. N. A. (2011). E-Commerce Adoption Among Small and Medium Enterprises in Saudi Arabia. (Unpublished doctoral dissertation). Universiti Utara Malaysia, Malaysia.

Awa, H .O., Ojiabo, O. U., \& Orokor, L. E. (2017). Integrated technology-organizationenvironment (T-O-E) taxonomies for technology adoption. Journal of Enterprise Information Management, 30(6), 893-921. 
Awa, H., Ukoha, O., \& Emecheta, B. (2015). Integrating TAM, TPB and TOE frameworks and expanding their characteristic constructs for e-commerce adoption by SMEs. Journal of Science and Technology Policy Management, 6(1), 76-94.

Awa, H. O., Ukoha, O., \& Emecheta, B. C. (2016). Using T-O-E theoretical framework to study the adoption of ERP solution. Cogent Business \& Management, 3(1), 1196571.

Cavana, R. Y., Delahaye, B. L., \& Sekaran, U. (2011). Applied Business Quantitative and Qualitative Methods. Sidney: John Wiley \& Sons.

Chang, S. L. (2006). Organizational, technological and environmental determinants of Ecommerce adoption in SMEs in Taiwan (Unpublished doctoral dissertation). Lyn University, USA.

Doherty, N. F., \& Fulford, H. (2006). Aligning the Information Security Policy with the Strategic Information Systems Plan. Computers \& Security, 25, 55-63.

Eid. M. I. (2011). Determinants of e-commerce customer satisfaction, trust, \& loyalty in Saudi Arabia. Journal of Electronic Commerce Research, 12(1), 78-93.

Elmazi, I., Vukaj, H., Gega, E., \& Elmazi, L. (2011). Information technology and its effects in SME. The case of Albania. International Journal of Management Cases, 13(4), 291-298.

Ghazali, I. (2005). Model Persamaan Struktural - Konsep dan Aplikasi dengan Program AMOS Ver. 5.0. Semarang, Indonesia: Badan Penerbitan Universitas Dipenogora.

Gilaninia, S., Danesh, S. Y., Amiri, M., Mousavian, S. J., \& Eskandarpour, B. (2011). Effective Factors on Adoption of E-Commerce in SME Cooperative. Interdisciplinary Journal of Contemporary Research in Business, 3(6), 144-161.

Grandon, E., \& Pearson, J. M. (2004). Strategic value and adoption of electronic commerce: an empirical study of Chilean small and medium businesses. Journal of Global Information Technology Management, 6(3), 22.

Hu, L. T., \& Bentler, P. M. (1999). Cutoff criteria for fit indexes in covariance structure analysis: Conventional criteria versus new alternatives. A Multidisciplinary Journal, 6(1), 1-55.

Jantan, M., Ramayah, T., Ismail, N., \& Hikmat, A. (2001). The CEO and AMT Adoption in Malaysia Small and Medium Scale Manufacturing Industries. Proceeding of the 10th International Conference on Management of Technology. Lausanne: Switzerland.

Kiarie, P., Henry, M., \& Rong, C. (2018). Dynamics of Technology Transfer for Innovation Processes in a Constrained Resource Settings: The Promise of Data Analytics and Computer Simulations. Computer Science and Engineering, 8(2), 30-39.

Kock, N. (2011). E-Collaboration Technologies and Organizational Performance: Current and Future Trends. Hershey, New York: Information Science Reference.

Lertwongsatien, C., \& Wongpinunwatana, N. (2003). E-commerce adoption in Thailand: An empirical study of small and medium enterprises (SMEs). Journal of Global Information Technology Management, 6(3), 67-83.

Lip-Sam, T., \& Hock-Eam, L. (2011). Estimating the determinants of B2B e-commerce adoption among small \& medium enterprises. International Journal of Business and Society, 12(1), 15-30.

MacGregor, R., \& Vrazalic L. (2008). A profile of Australian regional SME non-adopters of ecommerce. Small Enterprise Research, 16(1), 27-46.

Malaysia Digital Economy Corporation (MDEC). (2020). Digitalising SMEs. Retrieved from https://mdec.my/digital-economy-initiatives/for-the-industry/sme/

Marsh, H. W., \& Hocevar, D. (1985). Application of confirmatory factor analysis to the study of self-concept: First- and higher order factor models and their invariance across groups. Psychological Bulletin, 97, 362-582. 
Nunnally, J. C. (1978). Psychometric Theory. Michigan: McGraw-Hill.

Pihie, Z. A. L., Bagheri, A., \& Sani, Z. H. A. (2012, September 20-21). Exploring Regulatory Focus, Entrepreneurial Intention, Self-Efficacy and Entrepreneurial Skills Among Malaysian Higher Learning Institution Students. In Vivas C. \& Lucas, F. (Ed.), Proceedings of the 7th European Conference on Innovation (ECIE 2012) (pp. 430-437). Santarem, Portugal.

Saffu, K., Walker, J. H., \& Mazurek, M. (2012). Perceived Strategic Value and e-Commerce Adoption among SMEs in Slovakia. Journal of Internet Commerce, 11(1), 1-23.

Schumacker, R. E., \& Lomax, R. G. (2004). A beginner's guide to structural equation modelling $\left(2^{\text {nd }} \mathrm{Ed}\right)$. Mahwah, New Jersey: Lawrence Erlbaum Associates.

Sekaran, U. (2003). Research Methods for Business: A Skill Building Approach (4 ${ }^{\text {th }}$ Ed). New Jersey: John Wiley \& Sons.

Seyal, A. H., \& Rahman, M. N. A. (2003). A preliminary investigation of e-commerce adoption in small \& medium enterprises in Brunei. Journal of Global Information Technology Management, 6(2), 6-26.

Shah Alam, S., Ali M. Y., \& Mohd Jani, M. F. (2011). An empirical study of factors affecting electronic commerce adoption among SMEs in Malaysia. Journal of Business Economics and Management, 12(2), 375-399.

SME Corporation Malaysia. (2019). SME Annual Report 2018/2019. National Entrepreneur and SME Development Council (NESDC). Retrieved from https:/www.smecorp.gov.my/images/SMEAR/SMEAR2018_2019/final/english/SME\%2 0AR\% 20-\%20English\%20-\%20All\%20Chapter\%20Final\%2024Jan2020.pdf

Soh, C., Mah, Q. Y., Gan, F. J., Chew, D., \& Reid, E. (1997). The use of the Internet for business: The experience of early adopters in Singapore. Internet Research: Electronic Networking Applications and Policy, 7(3), 217-228.

Stroehle, F. (2008). Effective E-Commerce in China Lessons from cross-cultural research. Otago Management Graduate Review, 6(2), 65-79.

Mahalingam, E. (2018, August 20). Opportunities in e-commerce. The Star Online. Retrieved from https://www.thestar.com.my/business/smebiz/2018/08/20/opportunities-inecommerce/

Tornatzky, L. G., \& Fleischer, M. (1990). The processes of technological innovation. Lexington, MA: Lexington Books.

Vandenberg, R. J., \& Scarpello, V. (1994). A longitudinal assessment of the determinant relationship between employee commitments to the occupation and the organization. Journal of Organizational Behavior, 15(6), 535-547.

Wanyoike, D. M., Mukulu, E., \& Waititu, A. G. (2012). ICT Attributes as Determinants of Ecommerce Adoption by Formal Small Enterprises in Urban Kenya. International Journal of Business and Social Science, 3(23), 65-74.

Wu, F., Mahajan, V., \& Balasubramanian, S. (2003). An analysis of e-business adoption and its impact on business performance. Journal of the Academy of Marketing Science, 31(4), 425-447. 